\title{
JOSEPH LISTER 1827-1912
}

\section{A Bibliographical Biography}

\author{
J. G. Bonnin and W. R. LeFanu, ${ }^{*}$ London, England
}

Chance favours the mind which is prepared-Pasteur.

No date can be assigned to Lister's development of the germ theory of wound infection; so no fixed date of celebration can be chosen. August 12,1865, was the day on which the inward and invisible conviction resulted in the outward and visible application of carbolic acid to a compound fracture for the first time, and has already and justly been celebrated; but it was not until March 16,1867, after further work that the method was made public in the Lancet, in a series of four articles, and battle with the reactionaries opened. The first publication of the method seems the appropriate day for the Journal to acknowledge our professional indebtedness to Lister.

The first steps of the " father of safe surgery " went unrecognised. The Lancet spread the articles over four discontinuous issues and sandwiched the first between an article on diseases of the liver and one proving that lithotrity was an eminently successful operation, at least in so far as it increased the surgeon's earnings. It is easy to see, reflected in the virulent opposition encountered by Lister, the importance of his discovery and the social problems it produced, but it is impossible to return to the past and to recapture the personal and social emotions of the period on which these feelings were based.

The world was naive in those days: the Lancet of that year contained speculations on the possible fate of Livingstone in an emotional endeavour of an essentially similar inspiration to Lister's. The Sanitary Commission investigating the state of the infirmaries and workhouses was reported in this issue, and the following extract gives a clue to the social and mental development of the community at that time, which might well replace many pages of doctrinaire analysis: "A new water closet has been built in contact with the men's ward and it is contemplated to do the same with the women's. Above all, three paid nurses have been engaged at salaries of twenty-five pounds, their ages being thirty, forty-six and forty-nine. So great a boon has this proved to be that it is in contemplation to appoint night nurses."

Many attempts have been made to recapture the insalubrity of the hospitals in order to emphasise the conditions that Lister left behind him. In that year Great Britain was scourged by an epidemic of dysentery and relapsing fever; cholera was pandemic. The sewage system of London dates from 1847 and the sewage was discharged out to sea. Half the medical wards were occupied by typhoid cases, and childbed fever was the common accompaniment of a birth in hospital. The soul-racking fear of surgeon and patient alike was sepsis either in the localised form of abscess or the generalised forms of pyaemia and septicaemia, which frequently started with the massive mixed infection of wounds commonly called "hospital gangrene." The surgeon who operated in filthy clothes and a dirty room without the benefit of anaesthesia saw his results destroyed by infection and developed a hardness and lack of sensitivity as a protection against the demonstrable failures of his work. It was commonly held that the activities of the surgeon were his responsibility and the sequelae were God's responsibility: the surgeon thus conveniently shed the burden of his late results. When Lister showed that the surgeon should be and was responsible for the effects of the operation the

* Librarian, Royal College of Surgeons of England. 
wrath of many surgeons knew no bounds; they could no longer escape their responsibilities, and their feeling that Lister was endeavouring to place heavy and unnecessary burdens upon them lent vindictiveness to their opposition.

There are few great men whose public lives and private lives have reflected each other with such accuracy as Lord Lister's. It is surprisingly easy to trace the family influence on the cast of his mind and the determination and growth of his interests, and there is a continuity in his work and papers indicative of his implacable and, at times, austere devotion to the principles of antisepsis. However, his papers could be easily contained in one octavo volume of 500 pages, and this, in a world where overwriting has become a habit, perhaps points a moral.

Lister's father plays a much more important part in the development of his son's interests than do most parents. Parents may be responsible for the moral and emotional tone of their offspring but are not responsible for the mental acuity of their children and the direction it will take. Joseph Jackson Lister was responsible for both. As a wine merchant in the City he travelled, and his travels, as befitted a Quaker, took him to a school of the "Society of Friends." Here he met Isabella Harris, the daughter of the School Superintendent, renowned in the school for elocution and the sympathy and understanding of her reading aloud. They married in 1819 , and Joseph Lister was their fourth child of seven. His schooling was naturally at private Quaker schools where he did well, and his Quaker upbringing accounts for much of his character. He was open and direct, transparently honest and devoid of affectation. He scorned luxury, led a simple life and lived as quietly as his fame in later years permitted. His emotions always remained under control. Even though he was more provoked than Pasteur, he never slipped into mere vituperation as Pasteur did when attacked in the ill-edited posthumous works of Claude Bernard. His character, though warm and stimulating, could be a little forbidding at times, and this austerity was some check to his exuberant friends. Not

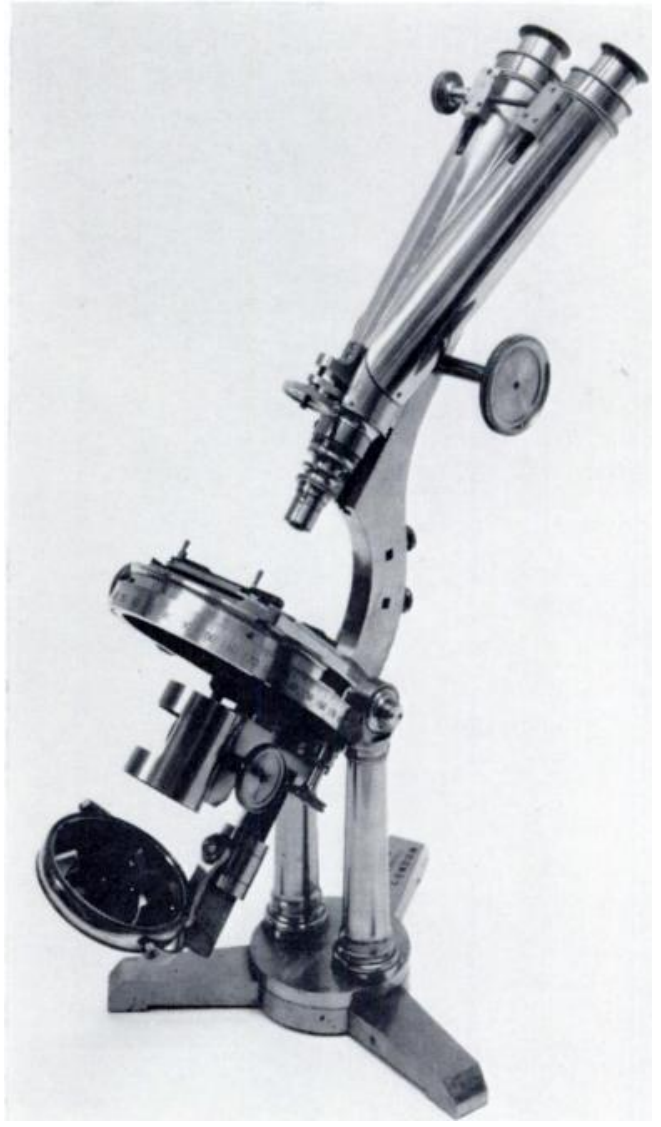

Microscope used by Lister's father, Joseph Jackson Lister. profoundly religious, his projection of the gospel of antisepsis was essentially religious-a crusade based on the love of men and a hope for the betterment of their conditions. On his marriage to Syme's daughter, not a Quaker, he was compelled to resign from the Society of Friends and adopted the Episcopalian Church. As witness to his freedom from the selfabnegation that the Society imposed, he bought a brass door plate with "Mr Lister" on it. In the Society of Friends he would merely have been Joseph Lister.

The direct influence of father on son is most clearly shown in the use to which he put the microscope. His father left school at fourteen years of age. He managed to gain for himself sufficient optical knowledge to be elected a Fellow of the Royal Society and was instrumental in developing the achromatic lens. ${ }^{35}$ Lister not only inherited his father's ability and determination but was directed into microscopical research by his father's interests, and to 
this we owe the early papers which prepared the way for his bacteriological researches. His first paper appeared in the Quarterly Journal of Microscopical Science in 1853 as "Observations on the Contractile Tissue of the Iris." In this he was able to add to Kölliker's work on the mechanism of contraction and dilation of the pupil. This was followed by similar work on the muscular tissues of the skin. ${ }^{2}$ Both papers were illustrated by careful line drawings. It is notable that the ability to draw was also possessed by his father, who extended his scientific drawings to live portraiture, leaving excellent sketches of his father and mother.

Lister started his medical training at University College Hospital in 1844 at the age of seventeen. His first three years were marred by an attack of smallpox and a nervous breakdown

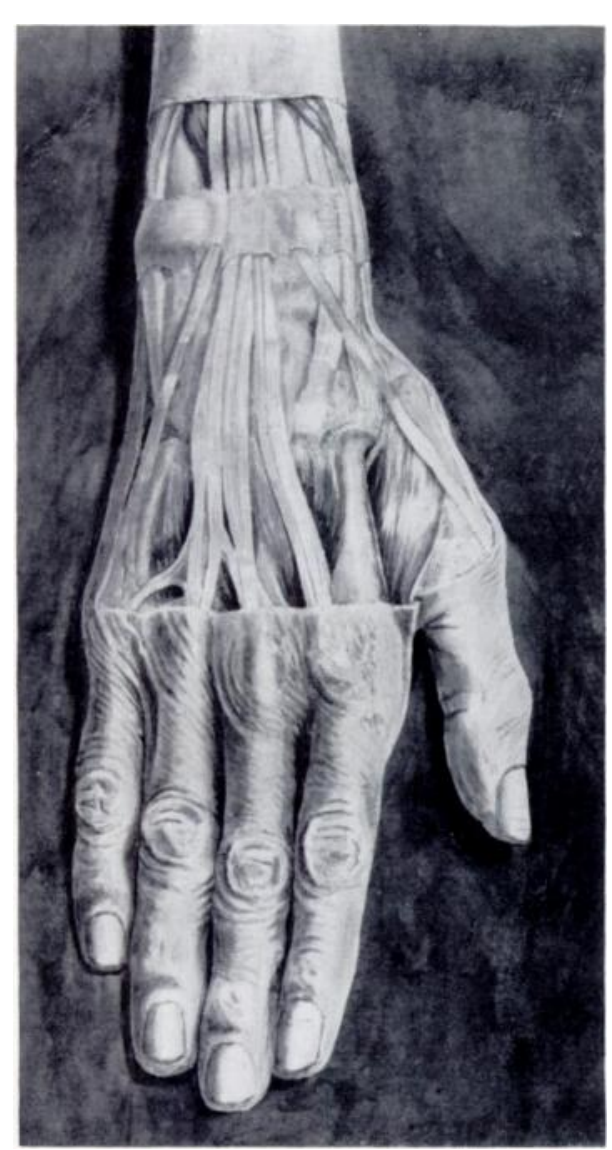

A characteristic drawing of Lister's used for illustrating the approach in the operation for tuberculous wrist. from overwork. In his clinical years he came under the influence of Sharpey, Professor of Physiology, and Wharton, Professor of Ophthalmology, and this helped to direct his thoughts to the papers mentioned above. Lister commenced surgery after the discovery of anaesthesia and was present at the first operation done by Liston under ether at University College Hospital in December 1846. After graduation he served as house physician to Walshe and house surgeon to Erichsen. His impression of surgery was one of sad disillusion. Hospital sepsis undermined any control the surgeon exerted on the results of his operations, and recovery or death seemed a matter of chance. In 1852 he got both his M.B. and F.R.C.S., and having spent nine years at University College Hospital he took a well deserved holiday of the " busman's" type in Edinburgh. "Chance," Pasteur said, " favours the mind which is prepared." He was of course referring to the prepared mind in which the seed of a thought is sown, so beautifully exemplified by Fleming's discovery of penicillin and less dramatically by Lister's elaboration of the germ theory of wound infection. The chances which favoured Lister in Edinburgh were those of time, place and personality. Lister's conscientiousness made him reluctant to embark on a surgical career with insufficient knowledge. Only wise men know their own ignorance. He therefore set out to visit Edinburgh attracted by Syme's great reputation. Rather to his surprise he found Edinburgh to be ahead of London. "The Infirmary," he wrote in a letter to his father, " is larger than I expected to find it; there are 200 surgical beds and a large number of other departments. At University College Hospital there were only about sixty surgical beds, so altogether a prospect appears to be opening of a very profitable stay here ... Mr Syme is I suppose the first of British surgeons and to observe his practice and hear the conversation of such a man is of the greatest possible advantage ..." In these sentences his future lies foreshadowed. The affection for Syme developed and the stay in Edinburgh was prolonged. He became Mr Syme's "supernumerary clerk," the duties being those of a non-resident house surgeon to assist at operations and generally watch over his cases. During this period he read a paper on exostoses to the Edinburgh Medico-Surgical Society, ${ }^{3}$ showing that ossification of the growth was the same as that of 
epiphysial cartilage. On returning from his Christmas holiday at his birthplace, Upton, he learnt of the sudden departure of Syme's house surgeon and Lister took his place temporarily. The temporary absence became a permanent one and Lister continued in his post until February 1855. In this position he supervised twelve dressers. Their estimate of Lister's capacity was summed up in the nickname they gave him, " The Chief," an estimate of character and a tribute of affection which clung to Lister for the rest of his life.

During the year 1854, the year of Lister's house surgeoncy, the Crimean War was raging and MacKenzie, who was regarded as Syme's successor, joined the services only to die of cholera. A successor to give MacKenzie's winter lecture course had to be appointed, and with some misgivings Lister accepted the post. On April 21, 1854, he was elected F.R.C.S. Edinburgh and took lodgings in 3 Rutland Street, opposite Syme's consulting rooms. A short visit to Paris preceded the work of preparation for the lectures, and in July he started work on them; by the end of the month, however, he acknowledged to himself and his family a considerable distraction, namely his growing affection for Syme's daughter Agnes. His natural wishes encountered some difficulties as marriage outside the Quaker circle necessitated his resigning from the Society of Friends, but on April 24, 1856, he was married to her.

Lister now had the pleasure of being his own master with his own rooms, and his first fee was received from a patient whose posterior dislocation of the ankle he reduced under chloroform anaesthesia. In September 1855 a letter records that he began the study of inflammation six weeks before his lectures were due to commence. The results appeared in a series of papers in $1856^{10}$ and $1857^{11}$ which ${ }^{14}$ led on to his studies on the lacteal flow in the mesentery ${ }^{15}$ and the coagulation of the blood $; i^{17}$ these were subsequently of some importance in the development of the ligature under the antiseptic system. Other papers interspersed with these paid tribute to his energy and activity during this period, notably the first paper in 1856 on the "Minute Structure of Involuntary Muscle Fibre," 9 a purely histological study which failed to attract the appreciation it deserved.

His work on inflammation was carried out on the web of a frog's foot and formed the basis of all subsequent observations on this subject. He failed to detect the migration of the white blood corpuscles through the capillary walls, subsequently described in 1867 by Cohnheim. His work on the pigmentary system of the frog ${ }^{13}$ was also of physiological importance.

On Wednesday, November 7, 1855, the course of lectures on the "Principles and Practice of Surgery" commenced. After preparation for the first lecture he was left with only one hour's sleep, but the lecture gained the applause of an audience of fifty students. Twenty-one foolscap pages of notes backed up the lecture, but he subsequently became less dependent on notes, though the habit of last minute preparation grew on him and final amendments often delayed his arrival on the platform.

His marriage was followed by a honeymoon on the Continent of three months duration, a happy and successful trip in which his work bore fruit in entertaining contacts with Paccini and Rokitansky among many others. Returning to Edinburgh they settled at No. 11 Rutland Street and he began negotiations with the managers of the Royal Infirmary for an Assistant Surgeoncy; to this he was elected on October 13, 1856. The number of students attending his regular lectures had now fallen to eight but work on coagulation of the blood ${ }^{17,23}$ continued. On February 25, 1857, he made his début in the hospital operation theatre, amputating a great toe and carrying out a radical cure for hernia. Both operations caused him considerable anxiety, but he was satisfied he had acquitted himself well. This anxiety was part of Lister's deep concern and interest in his patients and contributed to their affectionate regard for him. A visit to the British Medical Association meeting in Dublin followed in 1857, ${ }^{15}$ when the paper on lacteal flow was delivered. In November 1858 he had the doubtful satisfaction of commencing his lectures to a single student though seven arrived later.

In 1858 and 1859 Lister's private work grew slowly. Mrs Lister referred on one occasion to "poor Joseph and his one patient," but if not financially rewarding years they were

VOL. $49 \mathrm{~B}$, NO. 1. FEBRUARY 1967 
productive. Papers were read on ligation, ${ }^{18}$ amputation ${ }^{21}$ and coagulation of the blood. ${ }^{23}$ Those interested in trauma will appreciate this extract from a letter to his father: "June 8, 1858 . . . A poor woman had the lower part of her leg crushed by a railway carriage and I was called to the Infirmary to amputate the injured part. Now in these railway accidents it is often a matter of great difficulty to decide by the appearance of the surface what amount of injury has been done to the interior ..."

In 1859 the Regius Professor of Surgery at Glasgow resigned and Syme at once advised Lister's possible candidature. The election, conducted with some curious and undesirable publicity in the Glasgow Herald, was eventually made on January 28, 1860. A complimentary dinner to celebrate his election and his seven years in Edinburgh was accompanied by the presentation of a silver flagon. Lister's reply to the toast of his health caused him some trouble to prepare and reflects the heavier style of the period and his own serious and generous nature.

After a year Lister was in the curious position of being a Professor without a hospital appointment, but when it came the clinical opportunities were far greater than in Edinburgh, Glasgow at this date being almost twice the size of Edinburgh. Lister was the third occupant of the chair of surgery established in 1815. The induction took place on March 9,1860, and involved Lister in the delivery of a Latin thesis, an acknowledgment of the importance of the established "lingua franca" of the past. The preparation of this speech did not start until 2 a.m. on the day of the inauguration. The commencement of his summer course of lectures marked the abandonment of lecture notes; his subsequent lectures were mainly extempore and were a great success and much better attended than his colleagues anticipated. In the winter session his closing statement at the end of the first lecture epitomised his own attributes. He demanded of the medical profession "first a warm loving heart and secondly truth in an earnest spirit."

In August 1861 he contributed an article on amputation to Holmes's System of Surgery; ${ }^{24}$ in this he traced the history of amputation from Hippocrates to Larrey, including Morel's discovery of the tourniquet in 1674. His original contributions were his recommendation of amputation through the knee and his use of the abdominal tourniquet in amputation through the hip joint. In this he was anticipated by an American surgeon, Joseph Pancoast, in 1860. $\mathrm{He}$ also drew attention to the importance of elevation of the limb in obtaining a bloodless field, subsequently rendered unnecessary by the use of Esmarch's bandage. This was discussed in more detail in a paper read to the Harveian Society of London in $1879^{69}$ and to the Medical Society at University College Hospital in 1882.80 As befitted his general interests as Professor he wrote the article on anaesthesia in Holmes's System of Surgery $;^{25}$ in this he recommended the use of chloroform with free access of air. In later additions to this article in $1870^{42}$ he commented favourably on nitrous oxide, and in $1882,{ }^{82}$ on the increasing use of ether, though he still remained attached to the use of chloroform administered by a senior student in preference to the " great majority of qualified practitioners." Curiously enough he remarked that the heart should not be examined before anaesthesia because of the alarm such an examination might engender. The articles are important because they describe laryngeal stertor and emphasise the value of pulling the tongue forward. Further evidence of his catholic interests was given by a series of lectures on diseases of the eye.

In June 1864 James Miller, the Professor of Systematic Surgery in Edinburgh, died, and Lister, with some reluctance, but confidently, applied for the post. The unexpected happened and the post was given to a Mr Spence. Edinburgh thus lost the direct credit for the antiseptic system which was to be fully developed in his remaining five years in Glasgow. In 1864 he was preoccupied with rebuilding the College Hospital (now the Western Infirmary), Gilbert Scott being the architect chosen. In this year he also devised an instrument for removal of foreign bodies from the ear and improved on Syme's method of dealing with urethral stricture.

As mentioned before, 1865 saw the introduction of the antiseptic system. This was the year in which the first Atlantic cable was laid, to the credit and interest of a fellow Professor, 
William Thompson, later Lord Kelvin, scientific adviser to the Great Eastern. In this year also Lister's first paper on excision of the carpal bones for tuberculous disease appeared, ${ }^{27}$ which was expanded later in an address to the Medico-Chirurgical Society of Edinburgh in 1871. ${ }^{47}$ Lister's slowly developing ideas on sepsis grew directly from his knowledge of Pasteur's work. He had hoped that the new College Hospital would be cleaner than the old, "but to the disappointment of all concerned this noble structure proved extremely unhealthy. Pyaemia, erysipelas and hospital gangrene soon showed themselves ..." The mortality of amputation in Edinburgh was 43 per cent, in Glasgow 39 per cent. Unknown to Lister, Semmelweiss, who died in 1865 , had related uterine sepsis to infection and in 1861 published his famous paper "Die Aetiologie, der Begriff und die Prophylaxis des Kindbettfiebers."

Confusion still existed between the natural decomposition of organic material exposed to the air and the role of microscopic organisms in encouraging decomposition. The aerobic and anaerobic organisms were discovered in 1861 when Lister first started to discuss decomposition on the basis of wound infection, and by 1865 Pasteur had clearly defined the roles of bacteria in decomposition. Lister had no appreciation at this time of the possibility of the entry of organisms into tissues other than through open wounds. In 1866 he applied for the chair of surgery at University College Hospital. Realising the value of his antiseptic discoveries, and in the hope that the knowledge of these might influence the choice of the committee, he sent a letter elaborating his views with his application. This application was unsuccessful, but the letter was published in $1867^{28}$ and thus became Lister's first public statement of the theory of antisepsis. Because of its precise analysis of his views at this time it is worth reproducing it here.

"Having been engaged, at the time when the present vacancy in University College Hospital was announced, in preparing for publication a new method of treating

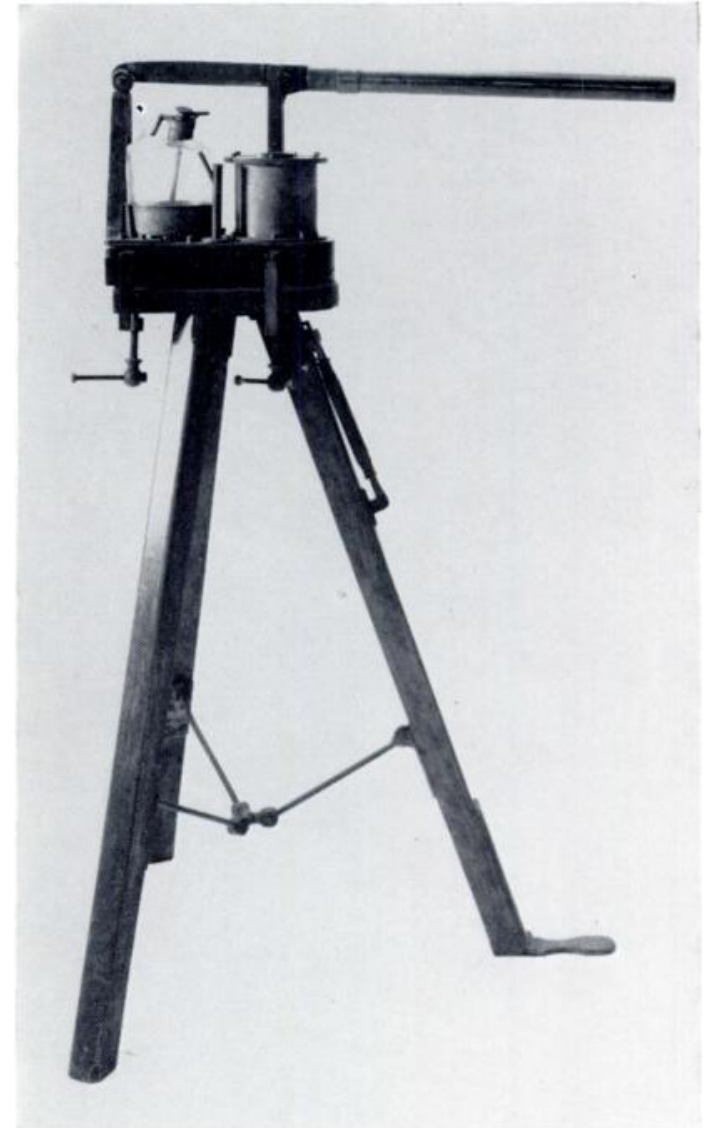

Lister's " Donkey Engine," which delivered such a heavy spray of carbolic acid that it had to be abandoned. compound fractures, which has for a long time past occupied my attention, I have thought it not unsuitable to give a short notice of it in this place. The disastrous effects of compound fractures as compared with the freedom from all danger of simple fractures, evidently depends essentially upon the fact that in the former the blood effused around the fragments being in communication with the external air through a wound undergoing decomposition, and being an acid irritant, produces more or less extensive death of tissue and suppuration, whereas in the latter, the blood retaining its natural bland character is converted into tissue, or got rid of by absorption. With regard to the mode in which the atmosphere produces decomposition of the blood, we know now, thanks to the beautiful researches of Pasteur, that the active agents are not the gaseous elements in the air, but minute living organisms suspended in it, which, by developing in a decomposing substance, determine a change in its chemical arrangement, analagous to

VOL. 49 B, NO. 1, FEBRUARY 1967 
the fermentation of sugar under the influence of the yeast plant. Hence it occurred to me that if in a compound fracture, before decomposition of the blood had set in, a material were applied to the wound, which, though it might allow the gasses of the air to penetrate, would destroy its living germs, all evil consequences might be averted. For this purpose I selected carbolic acid, having heard of its remarkable efficiency in disinfecting sewage, and about a year and a half ago, a case of compound fracture of the leg presenting itself, I applied to it lint dipped in the acid, and found my anticipations fully realised; the case progressing exactly

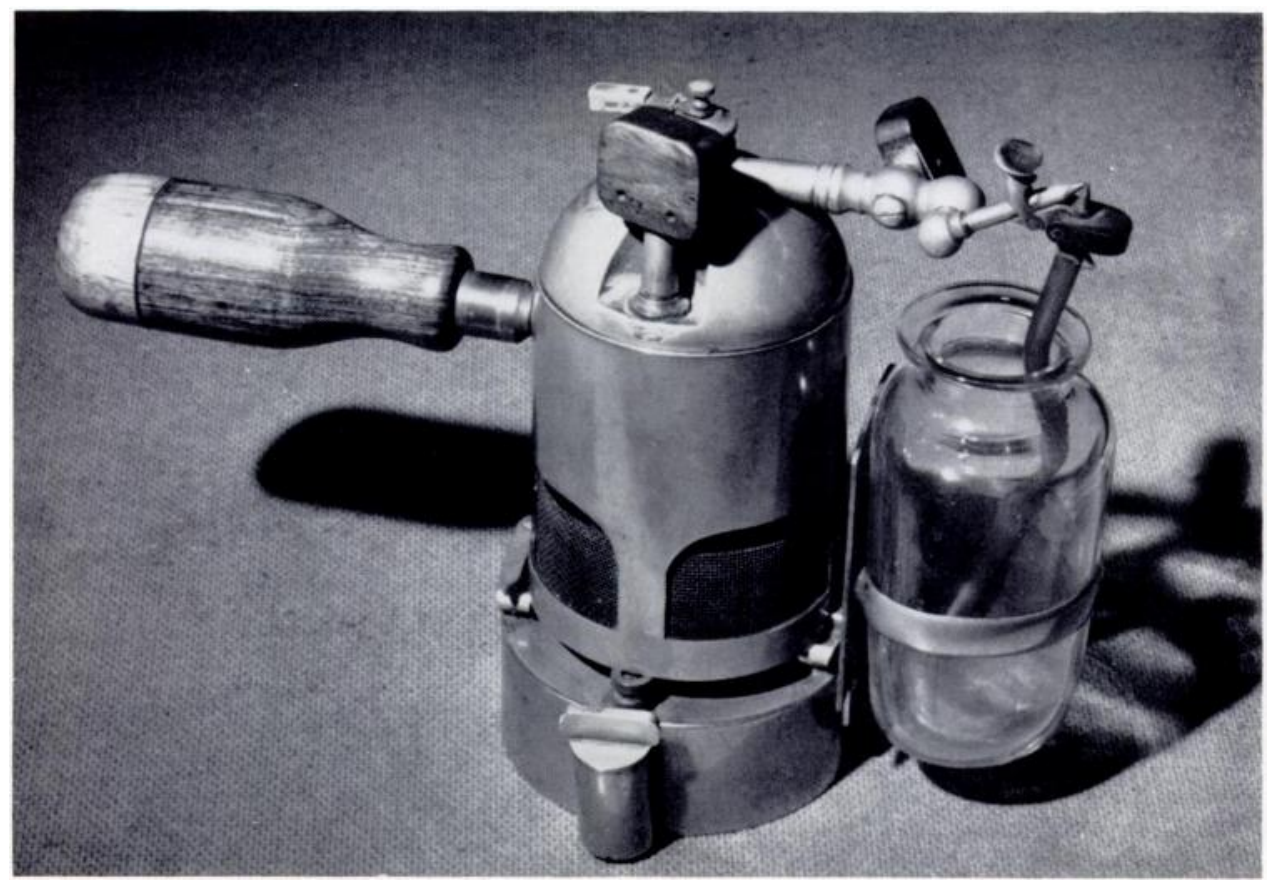

Lister's steam spray, the more general and widely used model.

like a simple fracture, as regards absence of suppuration, and of constitutional disturbance and rapidity of osseous union of the fragments. I have since subjected to the same treatment five other cases, some of them as bad as any surgeon would think of saving, and the results have been better than I have at first ventured to hope. The carbolic acid forms with the effused blood, a dense crust, which if touched daily with the acid, to ensure freedom from decomposition may remain for weeks without a drop of pus forming beneath it, thus affording abundant time for the absorption and organisation of the effused blood."

Lister was bitterly disappointed in his failure to be elected and returned to Glasgow to pursue the development of his theories in the series of papers which appeared in the Lancet in 1867.29 Realising the importance of this work, Syme advised him to read a paper at the British Medical Association meeting in Dublin in August 1867.30 In this paper Lister stated his views on the three varieties of suppuration encountered: 1) simple inflammatory suppuration such as that in which ordinary abscesses originate where pus appears to be formed in consequence of an excited action of the nerves independently of any other stimulus; 2 ) suppuration caused by a chemical (or a mechanical) stimulus; 3 ) suppuration caused by decomposition. Clearly at this stage Lister had some way to go to resolve his confusions, but had commenced to lay down his principles of treatment.

With increased publicity came misunderstanding and opposition. Sir James Young Simpson, possibly aggrieved by the failure to recognise his method of control of arterial haemorrhage by acu-pressure, Lister's antiseptic sutures having rendered the method 
superfluous, attacked Lister at the meeting and opposed his ideas. In a letter to a newspaper he attempted to credit Lemaire with the first surgical use of carbolic acid; this criticism was echoed in the Lancet and produced Lister's denial of any knowledge of Lemaire's work or of any claim to his priority in the use of carbolic acid. Simpson then wrote a derogatory attack in the Lancet, but Lister was not to be drawn and replied calmly.

Further lectures on the antiseptic system were given in $1868^{32}$ and $1869 .{ }^{34,36}$ In the latter year, as a sideline on antisepsis, he produced a paper on the development of the sterile absorbable catgut suture. ${ }^{33}$ Those wishing to learn more of Lister's contribution to the development of the ligature should consult Messrs Johnson \& Johnson's short volume Lister and the Ligature, 1925.

Modifications of dressings continued; oil silk covered with copal varnish was modified by a coating of dextrin and starch to prevent its total wetting with carbolic lotion. He moved further towards the modern concept of healing injured tissues: " all they need is to be left alone." Following the use of putty impregnated with carbolic acid the Lac plaster was developed. The many minor changes in methods of procedure confused his critics and distracted them at times from their attention to the main principles of his reasoning.

On October 24, 1869, Lister's father died. He wrote an obituary notice in the Monthly Microscopical Journal in $1870^{35}$ and subsequently expanded it for the entry in the Dictionary of National Biography (1893). ${ }^{96}$ His father's death was an intense sorrow to Lister; in revealing letters throughout his life he had shared his thoughts with his father, to whose early training he recognised his indebtedness. He paid his last visit to his birthplace, Upton, arriving a few days before his father's death, and subsequently wrote to his brother of his hope, "may I too meet thee (his father) on that peaceful shore."

Some time before April 1869 Syme had a stroke, and in considering his successor hoped that Lister might get the Edinburgh Chair of Systematic Surgery; in this he had the support of the Edinburgh students, 127 of whom wrote to encourage him in his candidature. On August 18, 1869, he was elected, and moved to Edinburgh shortly after the death of his father-in-law, whose obituary notice he wrote also. ${ }^{40}$ He then settled at 9 Charlotte Square. The departure from Glasgow was marred by some ill-feelings. Lister published an outstanding paper "On the effects of the antiseptic system of treatment upon the salubrity of a surgical hospital." 36 In this he criticised the support given him by some of the administrators of the hospital: "I may add that my wards have remained during the three years without their annual cleaning." Not unnaturally the directors of the hospital replied belittling the service Lister had performed in reducing sepsis, and Lister, feeling that this had cast aspersions on the value of his system to which he was becoming more fervently attached, responded to the attack, though his natural training was to preach the gospel of antisepsis and turn the other cheek to criticism.

Among his colleagues at Edinburgh were Matthews Duncan the gynaecologist, Thomas Keith the pioneer of ovariotomy, John Chiene who succeeded to the Chair of Clinical Surgery, and the prototype of Sherlock Holmes, Joseph Bell. With these congenial colleagues Lister was happy. One important person who ministered to his satisfaction with his work was Mrs Porter, the Head Nurse in his ward, a character reported to keep all the members of her staff, the students and Lister himself in order. Lister was particularly dependent on disciples of every kind; principles were often submerged in detail and the details sometimes became the more important. Only a devotee could be trusted to pursue the meticulous course of treatment he demanded. This at times occasioned criticism; when he came to King's College Hospital he brought his own house surgeon and sister with him and this excited some jealousy amongst the displaced staff and the less privileged surgeons.

Lister now spent all his spare time in bacteriological culture and experiment. He published some papers of interest to the orthopaedic surgeon, one case of compound dislocation of the ankle,$^{38}$ another on anterior dislocation of the hip, ${ }^{45}$ a further paper on excision of the wrist

VOL. 49 B, NO. 1, FEBRUARY 1967 
for tuberculous osteitis ${ }^{47}$ and on rupture of the axillary artery in a dislocated shoulder, ${ }^{48}$ and also a paper on multiple loose bodies in the elbow. ${ }^{50}$

The bacteriological papers appeared between $1873^{49,54,66}$ and 1881 , the last being on the "Relation of Minute Organisms to Inflammation." 76 Lectures and demonstrations on antiseptic surgery continued throughout this period, including a lecture at the Charity Hospital in New York in $1876^{61}$ and at the International Medical Congress at Philadelphia in the same year. ${ }^{62}$

Lister's work with yeasts now brought him into direct contact with Pasteur, whose studies on fermentation had done so much to control the methods of brewing, and Pasteur was so gratified by a letter Lister wrote that he republished it in full in " Etudes sur la Bière " in 1876.59 Pasteur sent a critical reply pointing out some errors in Lister's work and apologising for his failure to write at greater length as he had had a stroke affecting his left side in 1868 .

Lister's concern with the air as the mechanism of transportation of infection now directed his attention to the development of an antiseptic spray, and a series of small hand and foot sprays to saturate the air around the operation site with carbolic vapour were followed by the large "Donkey Engine," a much more cumbersome appliance which overloaded the atmosphere with carbolic acid to the discomfort of surgeon and staff. This eventually gave way to the steam engine, a much more efficient portable machine. Lister in the end gave up the use of the spray, being aware from the beginning that it was " a necessary evil incurred to attain a greater good." He first publicly recommended the spray at a British Medical Association meeting in $1871^{46}$ and finally abandoned it in 1887, influenced by Metchnikoff's discovery of phagocytosis in 1883 and the further elucidation of the defensive system of the body.

Changes in the methods of dressing followed, a carbolic gauze being substituted for the Lac plaster; being simpler, this was more easily adopted. After the work of Koch on the effects of antisepsis on the destruction of organisms and spores and their inhibition by the use of corrosive sublimate he experimented with this. At this time he also did much to forward the practical use of rubber drains for deep sepsis. Pasteur suggested the use of boracic acid, long a popular but inefficient poultice, and even Charles Darwin wrote and recommended the use of benzoic acid.

Lister's confidence in his methods grew; he no longer hesitated to perform operations which were regarded as undue risks by other surgeons, not however by the knowledgeable ones such as Keith and Spencer Wells who practised Listerian principles. In 1868 he first turned a simple fracture of the femoral neck into a compound one by open operation and freshening of the fracture surfaces. This case caused great anxiety, and it was followed by severe secondary haemorrhage, finally controlled by packing the wound with carbolised lint. Successful healing followed. In 1868 he also removed a loose cartilage from the knee, describing this with enthusiasm in a letter to his father. In 1873 he opened an elbow joint and wired the olecranon. His practice of excising the wrist joint for tuberculous disease has already been commented on.

Lister's principles were now firmly established and further changes were merely modifications of the method in the light of experience. These were detailed in the Lancet in $1875 .{ }^{55}$ The years before this were given over to controversy, never acrimonious on the part of Lister, whose refutations were always touched with some regretful sadness. Indeed his attitude was rather like that of a discerning archangel rebuking the imps of Satan and aggravated some, but the annoyance melted immediately on meeting him. The subject of asepsis was much in the public eye and serious discussions took place at the British Medical Association meetings from $1867^{30,46,51}$ to $1889,,^{75,76}$ by which date the opposition was largely silenced. In 1875 the Lancet wrote: " Happily it is no part of the business of a clinical surgeon to bolster up theories be they good or bad, or to make facts rigidly conform to them. The germ theory may be perfectly well founded, but nine surgeons out of ten do not care much 
whether it is or not, so long as they cure their cases and reduce their mortality to the lowest possible degree." This shocking statement full of contradictions reflects on both the attitude of the Journal and of the surgeons of the time and epitomises the professional inertia which Lister encountered.

The opposition, which was perhaps more lethargic than vituperative, was persistent and included even those open to fresh ideas, such as Sir James Paget, who failed to follow Listerian principles carefully, and was disappointed. Interest and enthusiasm spread among the younger surgeons and Lister's fame abroad grew, particularly in Germany where the doctrine was expounded with new vigour, having been blessed by Bardeleben, Thiersch and Volkmann. The first book on the subject was written by Nussbaum in 1875 and ran rapidly through many editions and translations. Billroth though not an opponent remained unenthusiastic. Strangely enough the Americans were slow to accept the method, though much impressed by Lister's visit in $1876^{62}$ to the International Medical Congress in Philadelphia. The French, led by Lucas Champonnière and with the path prepared by Pasteur, were quicker, but the changes in Paris took time to spread to the Departments. The adulation of Lister in Germany was fully voiced by surgical leaders during his European tour in 1875 .

Lister had in 1876 been appointed to the General Medical Council, and his first considerations as a member were concerned with the "Cruelty to Animals Act" of that year. Renewed contacts with London colleagues awoke the never very somnolent desire to convert the metropolitan philistines. On February 10, 1877, in Lister's fiftieth year, Sir William Fergusson, Professor of Clinical Surgery at King's College Hospital, died. John Wood, then Professor of Systematic Surgery, hoped to succeed him. King's College Hospital, however, needed a powerful stimulus to attract students and perhaps the thought of rubbing into University College Hospital their loss of Lister attracted them, as King's College had been founded by members of the Church of England as a protest against " the godless college in Gower Street." Lister was secretly approached, rumours spread, and the agitated Edinburgh students rallied 700 signatures urging him to stay with them. Lister's reply to the presentation of this memorial mentioned "the magnificent opportunities for demonstrative teaching presented by clinical surgery are to a great extent neglected," when referring to the possibilities of teaching in London, and as a reporter was present unknown to him, this statement received unexpected publicity in The Times of the following day. Needless to say this did not endear him to his London colleagues and for some time it was thought that Lister had compromised his position. Nevertheless, negotiations were renewed and on June 18 Lister's conditions for accepting the appointment were agreed and a new Chair of Clinical Surgery created for him. He moved to London to rooms at 12 Park Crescent, convenient to a private hospital in Fitzroy Square. As method had now become as important as doctrine, Lister insisted on bringing with him to King's College Hospital two graduates, Watson Cheyne and John Stewart, and two unqualified assistants, Dobie and Altham. Nursing was also not neglected. In spite of Florence Nightingale's efforts Lister still had his doubts about the efficiency of London nursing staff and these were not relieved by a brush with them on the transfer of a patient of his from Edinburgh, when he encountered considerable difficulty in getting her admitted. Lister's first public lecture as a London professor was on "The Nature of Fermentation." 63 It was clear that he proposed to initiate his colleagues into the mysteries of his system by following the lines of development of the germ theory in his own mind, and as an example he chose to describe the activities of the bacterium lactis. The lecture was received with indifference. He was given few beds and had no patients to fill them. The contrast with Edinburgh and its 400 surgical beds and its enthusiasm was galling. The haphazard medical instruction in London compared badly with that of the more disciplined Scots. Students slowly increased in number but little in enthusiasm, the numbers attending his lectures being seldom more than a dozen. Wood, however, was an honest convert, and his other colleagues, if not enthusiastic, slowly grew to like and respect him. In 1877 when Lister wired a fractured

VOL. $49 \mathrm{~B}$, NO. 1, FEBRUARY 1967 


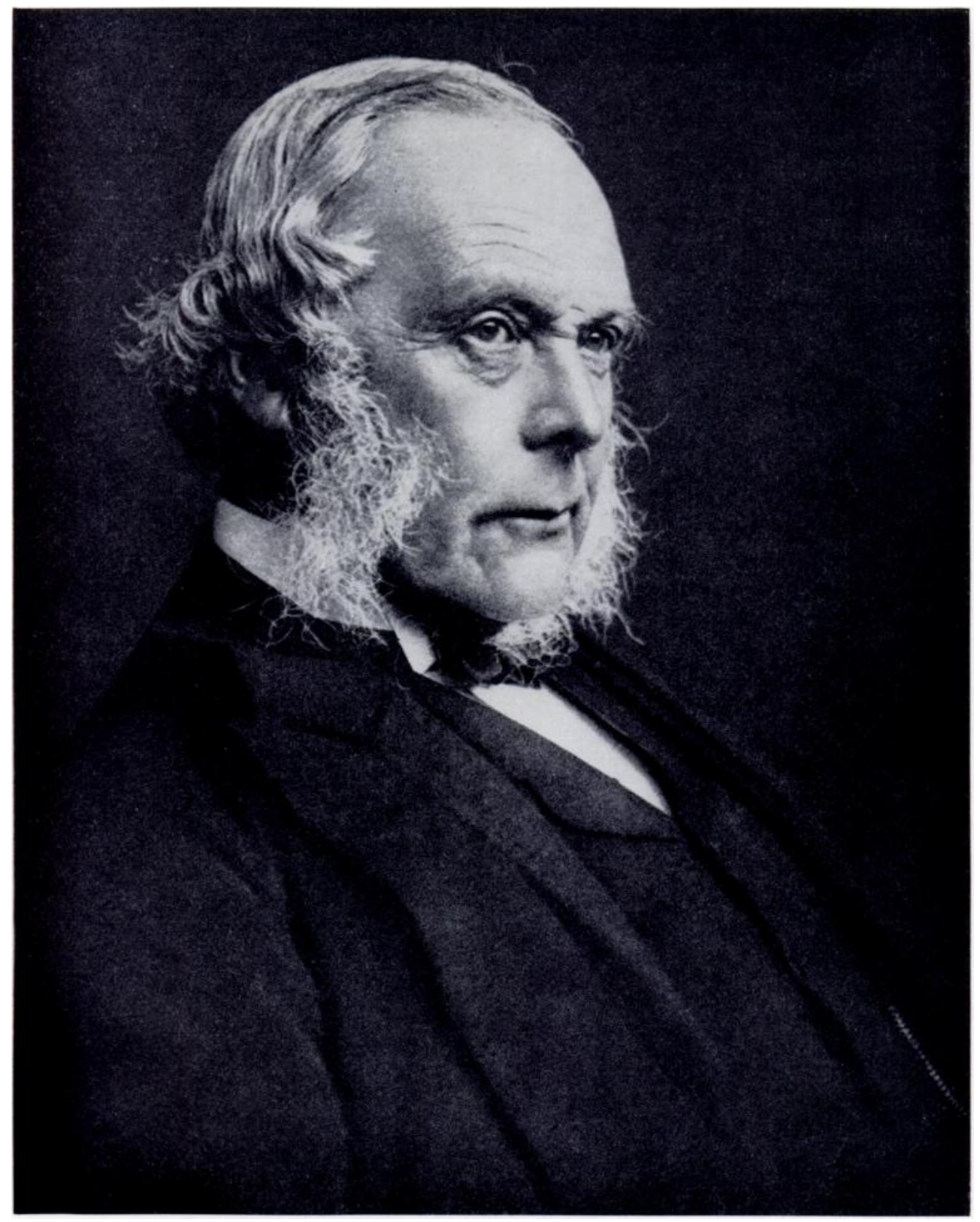

Lord Lister in later life, from a photograph by R. A. Bickersteth. 
patella a London surgeon is reported to have said: " now when this poor fellow dies, it is proper that someone should proceed against that man for mal-practice." As his surgical successes mounted and his natural humanity disarmed his antagonists, his influence steadily grew.

Invitations to lecture increased, first before the Pathological Society ${ }^{66}$ and then the Harveian Society. ${ }^{69}$ In 1878 he was sent to Paris on the recommendation of the Prince of Wales and met Pasteur. In 1879 at the sixth International Medical Congress in Amsterdam he received a standing ovation. ${ }^{73}$ The President, Professor Donder, took him by the hand and, obtaining a moment's silence, said, "Professor Lister, it is not only admiration that we offer you, it is our gratitude and that of the nations to which we belong."

In a lecture at Cambridge in August $1880^{76}$ Lister first referred to Robert Koch and his cultivation of micro-organisms in the mouse, and to Pasteur's work on vaccines and immunisation and the growth of ideas on the attenuation of virulence of the anthrax bacillus and fowl cholera. Bacterial knowledge was growing rapidly; in the next year it dominated the International Congress ${ }^{79}$ at which Koch and Pasteur were present, and a full debate took place on the causes of failure of primary union. The antiseptic system was now at its apogee. Further work was to substitute asepsis for antisepsis, one of the points of argument centering on the discovery of micrococci in wounds healing by first intention. The great protagonist of asepsis was Von Bergmann whose work was described by Schimmelbusch in 1892. Too much has been made of the opposition of the two systems which are handmaids to each other. Antisepsis persisted in the 1914-18 war in Carrel's solution for wound irrigation, and B.I.P.P. packing. How do we class the irrigation and insufflation of a wound with an antibiotic today?

Lister now gradually slipped into the role of an accepted and leading London consultant; the long campaign had reaped its reward. While clinical life in London was easier than in Edinburgh, social responsibilities and committee work increased. Lister, essentially a practical individualist, did not find committee work congenial, though he enjoyed the contacts with his colleagues on the Council of the Royal College of Surgeons to which he was elected in 1880, retiring in 1885 before he was eligible for the presidency.

Napoleon set the fashion by appointing the first surgeon to a Barony. The medical profession has paid for its historically late development by lacking the political power its importance to the community demands, and medical Baronies are rare in England. Foreign honours fell apace on Lister but not till 1883 was he made a Baronet. He was President of the Harveian Society in 1881-82 and an active member of the Hunterian Society. He read valuable papers to the Medical Society of London on four occasions, ${ }^{84,85,87,92}$ the paper of the greatest orthopaedic interest being that on the treatment of fracture of the patella. ${ }^{84}$ The furore occasioned in October 1877 by his converting a closed into an open fracture has already been mentioned; when he read his paper in 1883 he had collected seven cases. Wiring the two halves of the patella with silver wire was the logical outcome of wiring the olecranon, which he had already done three times in Edinburgh. His assistant, Hector Cameron, had already wired a patella in Glasgow in March 1877. Even in 1883 lively opposition to the procedure was encountered; one opponent, summing up, thought it was " magnifique mais ce n'est pas la chirurgie."

Pasteur's work on rabies resulted in the establishment of a centre for treatment in Paris, and consequently infected patients from all over Europe migrated there, the best known group arriving from Russia in 1886. Pressure for the establishment of a centre in London grew, and in spite of much anti-vivisectionist opposition the Jenner Institute of Preventive Medicine was opened in 1897. In 1903 the name was changed to the Lister Institute of Preventive Medicine and still continues its work. Lister was its first chairman and later president.

At the International Medical Congress in Berlin in $1890^{91}$ Lister received a tumultuous welcome. His paper was preceded by one of Koch's on the bacteriological developments which supported Lister's theories, though he was subsequently to be somewhat critical of

VOL. 49 B, NO. 1, FEBRUARY 1967 
Koch on certain aspects of tuberculous infection. Some of his last experiments were carried out on tuberculous infection in animals. In $1891^{93}$ at a similar large congress on hygiene in London he was president of the section of bacteriology and endeavoured to summarise the bacteriological advances since 1881. This congress brought together Laveran, who had discovered the malarial parasite, Roux, Adami, Ehrlich, Metchnikoff and Kitasato, and remains a landmark in the development of bacteriology.

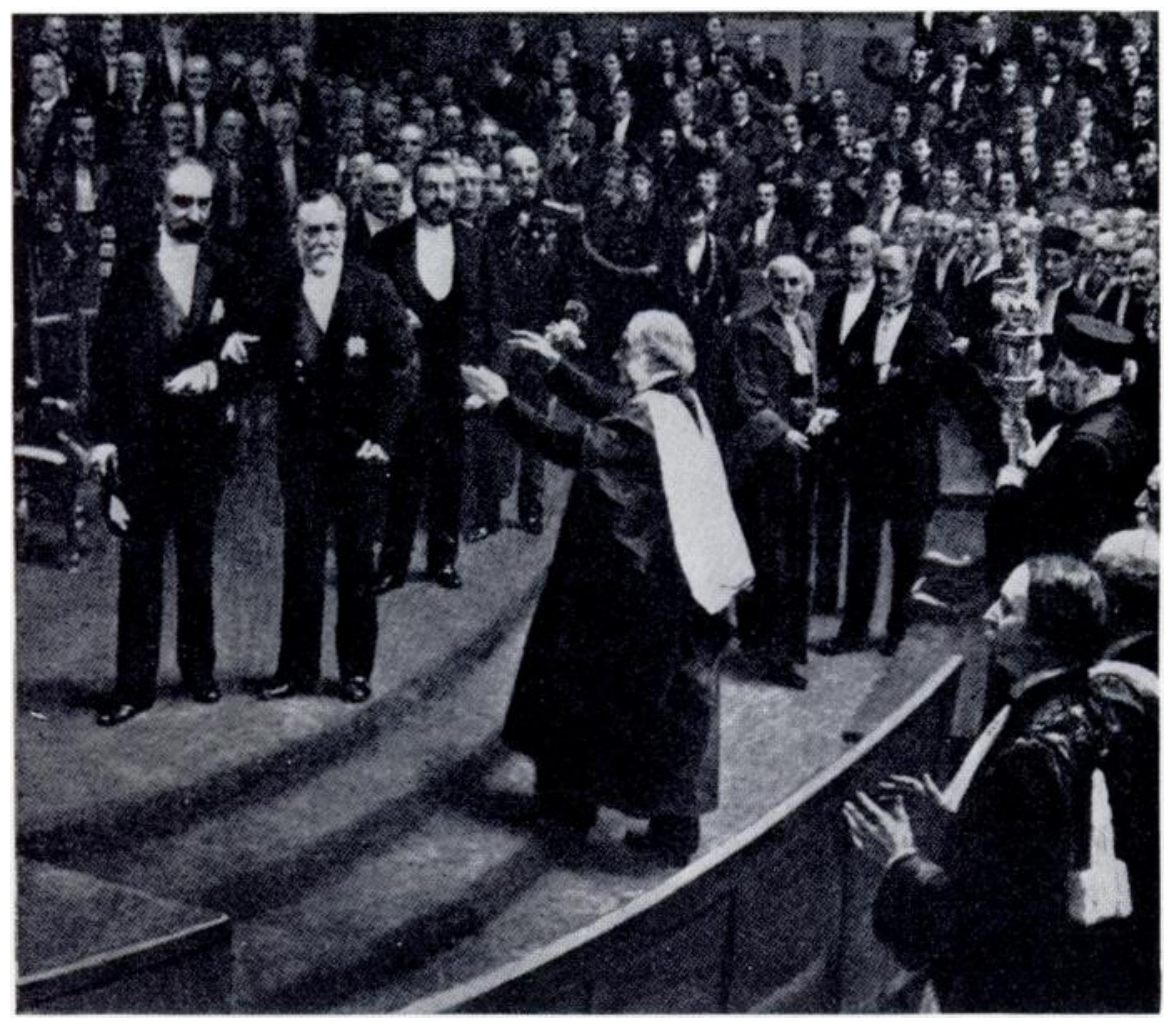

Central part of the picture by Rixens, showing Lister holding up his arms to greet Pasteur at a ceremony at the Sorbonne in Paris at the celebration of his seventieth birthday.

In 1892 physical age caught up with Lister and he was forced to retire at the age of sixty-five from King's College Hospital. Mental age scarcely seemed to affect him, and at the age of seventy he was still a clear thinker and a precise experimenter. His last clinical lecture appropriately related to the subject he had made his own, a resumé of antiseptic treatment.

Pasteur, only five years older, was broken in health by his incessant work and his stroke in 1868 , but now (1892) that he had reached his seventieth year the world united to honour him. At this extraordinary ceremony, in which the professional and lay world combined to honour a layman who had done more for medicine than anyone before him, Lister was the first professional representative to speak. His short address in French was followed by the scene so happily captured in Rixen's painting when Lister turned round to hold out his arms to Pasteur: "L'étreinte de ces deux hommes était comme la représentation de la fraternité de la science dans le soulagement de l'humanité." Pasteur, overcome with emotion, entrusted the reading of his reply to his son.

Soon after this Lister and his wife took a holiday at Rapallo, working and botanising. After they had been there for a week or two Lady Lister developed pneumonia and died within four days. The bond uniting husband and wife was very close; she had been his partner 
and inspiration in much of his work. The manuscripts in her hand at the Royal College of Surgeons testify to her assiduity, and the absence of a family closed the bonds of affection even more tightly around them. Lister never recovered from the blow, remaining thereafter a solitary and lonely man though he continued with his public and private duties.

In 1895 he was elected President of the Royal Society to which he had been elected a

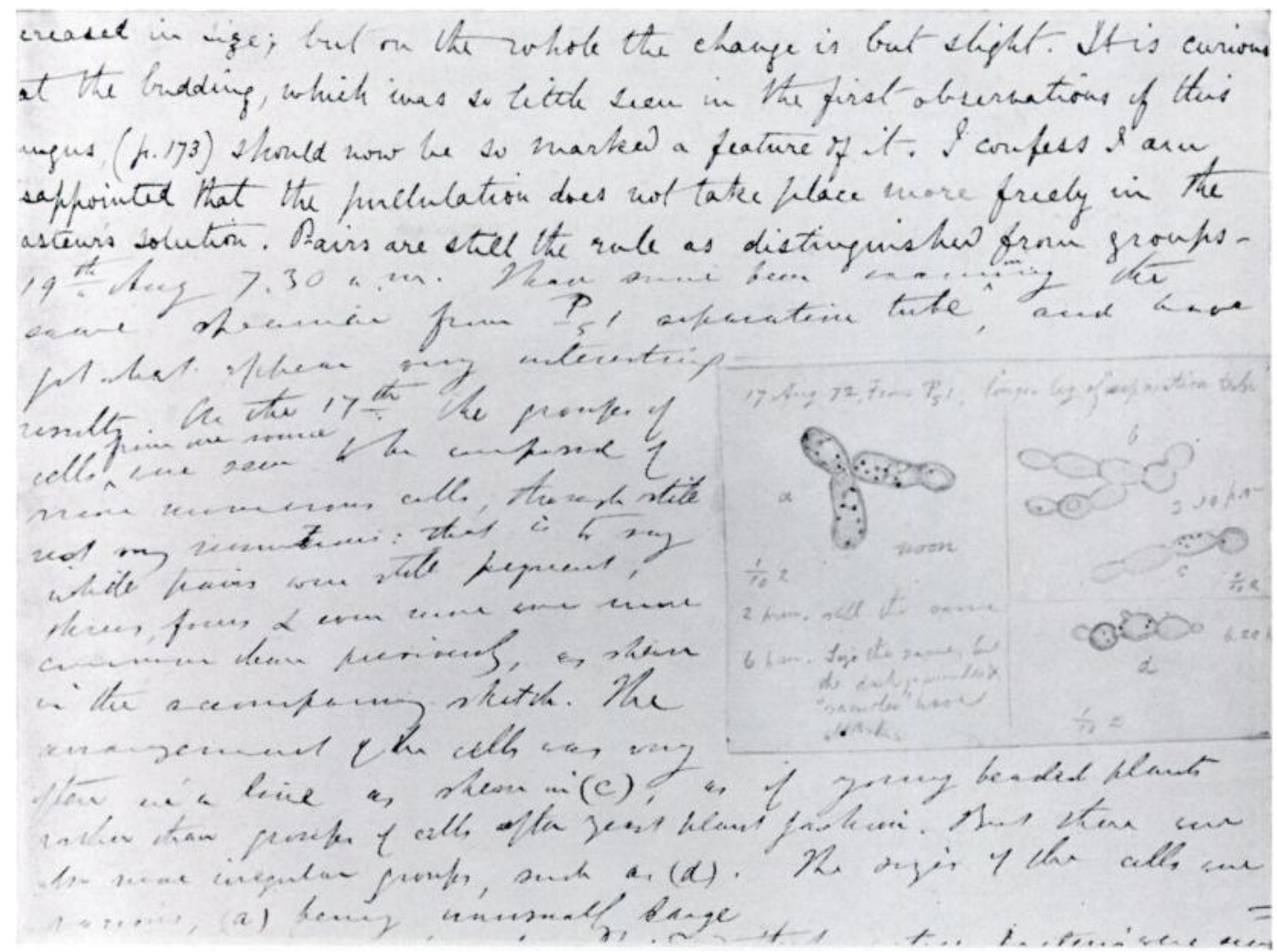

Part of a page from one of Lister's notebooks at the Royal College of Surgeons showing Lady Lister's handwriting at the top and Lord Lister's below and a small sketch of Lister's pasted in at the side.

Fellow in 1860 at the early age of thirty-six, and he held this post for five years.99, 104, 107, 108, 112 In 1896 he became President of the British Association, and at their meeting in Liverpool commented on the discovery of Roentgen in 1895 and the advances in immunisation. This was the year of Pasteur's death. In 1897 he was elevated to the Peerage, an occasion for a further round of congratulations, including a letter from Madame Pasteur and a eulogy at Belfast ${ }^{101}$ to which he replied dealing with the importance of pathology. He was recalled from this meeting to take part in the initiation of King Edward's Hospital Fund for London. Discussions in the House of Lords covered the health of British soldiers in India and the Vaccination Bill.

Many cities gave Lister their Freedom, many societies welcomed him as their president or guest, but after 1900 when he gave up the presidency of the Royal Society his activities declined and age made itself felt. In 1901-02 he took a holiday in South Africa and returned the day before the declaration of peace after the Boer War.

On June 24, 1902, he was present at the consultation on King Edward VII whose appendicitis had postponed the coronation, and was thus party to Sir Frederick Treves's decision to drain the appendical abscess. On the occasion of his coronation the King instituted the Order of Merit, of which Lister was one of the first twelve members appointed. In November he received the Copley medal of the Royal Society, and in 1903 an honorary degree from the University

VOL. $49 \mathrm{~B}$, NO. 1, FEBRUARY 1967 
of London. It was in this year while at Buxton in August that he probably had a small cerebral thrombosis which reduced his walking capacity and mental verve.

On April 5, 1907, Lister's eightieth birthday was celebrated throughout the world, Vienna leading the enthusiasm which was taken up by the British press and followed by numerous letters and addresses from learned societies. On June 28 he received the freedom of the City of London. The year 1909 saw the publication of his collected papers and the last communication he made-a letter to the British Medical Journal and the Lancet on chromic catgut. ${ }^{117}$ This was written from Walmer where he had gone for the bracing air, but failing sight and hearing prevented his return to London. Slowly his health failed and he slipped out of life almost imperceptibly on February 10, 1912. By general desire he would have been buried in Westminster Abbey, but he had expressed a wish to be buried beside his wife and joined her in the West Hampstead cemetery where his simple tomb may with some effort still be found.

Hard things have been said of Lister. These are the inevitable experiences of an innovator. He has been decried as a surgeon. His technique had neither the speed nor brilliance of the surgeons who preceded him, nor the refinements of the subsequent school of antisepsis. He has been denigrated as a speaker; his stammer though slight was a source of embarrassment. Yet as a deep, rich, pure and sympathetic character, as a prototype of the humane idealist, no one has surpassed him. Little wonder that Miss Cheatle, one of the last survivors to know Lister personally, when asked what Lister was like, replied " He was like God."

\section{LORD LISTER'S WRITINGS}

1 Observations on the contractile Tissue of the Iris. Quarterly Journal of microscopical Science, 1853, 1, 8-17. Reprint. Manuscript draft and drawings: R.C.S.

2 Observations on the muscular Tissue of the Skin. Quarterly Journal of microscopical Science, 1853, 1, 262-8 and Plate VI; dated June 1, 1853. Reprint.

3 Notes of the Examination of an Exostosis removed by Mr Syme on the 2nd of October, 1853, from the Os Humeri of a young lady aged about 20 years. (Read to the Edinburgh Medico-Chirurgical Society, Nov. 16th, 1853.) Monthly Journal of medical Science, January 1854, 18, 7-11. Reprint. See also no. 11.

4 Report of a case of Carbuncle occurring in Mr Syme's practice, illustrating especially the Pathology of that disease. Monthly Journal of medical Science, July 1854, 19, 43-46. Reprint.

5 Report of some cases of Articular Disease occurring in Mr Syme's practice, exemplifying the Advantages of the Actual Cautery. Monthly Journal of medical Science, August 1854, 19, 134-7. Reprint.

6 Report of some Cases of Maxillary Tumour. Monthly Journal of medical Science, Nov. 1854, 19, 428-434. Reprint.

$7 \mathrm{Mr}$ Syme and tenotomy. Letters dated Aug. 1855 and Oct. 1855. The Lancet, 1 Sept. 1855, 2, 204-5, and 10 Nov., pp. 447-50.

8 On a remarkable Case of Hydrocele. By Robert Lister. (Read before the Medico-Chirurgical Society of Edinburgh, April 16, 1856.) Edinburgh medical Journal, Sept. 1856, 2 (3), 236-9. Reprint.

9 On the minute Structure of Invc luntary Muscle Fibre. (Read 1st December, 1856.) Transactions of the Royal Society of Edinburgh, 1857, 21 (4), 549-557. Reprint. Also in Quarterly Journal of microscopical Science, 1858, 6, 5-14.

10 On the early stages of Inflammation, as observed in the Foot of the Frog. Read at the Royal College of Surgeons of Edinburgh on December 5th, 1856. (Summary.) Edinburgh medical Journal, January 1857, 2, 653-4. For full report see no. 14.

11 Case of pedunculated Exostosis. (Exhibited at Edinburgh Medico-Chirurgical Society, March 4th, 1857.) Edinburgh medical Journal, May 1857, 2, 1034.

12 An Inquiry regarding the Parts of the Nervous System which regulate the Contractions of the Arteries. Received, read June 18, 1857. Philosophical Transactions of the Royal Society, 1858, 148 (2), 607-625. Reprint: see no. 14.

13 On the Cutaneous Pigmentary System of the Frog. Received, read June 18, 1857. Philosophical Transactions of the Royal Society, 1858, 148 (2), 627-643, plates 47-48. Reprint: see no. 14.

14 On the Early Stages of Inflammation. Received, read June 18, 1857. Philosophical Transactions of the Royal Society, 1858, 148 (2), 645-702; in Edinburgh medical Journal, January 1858, 3, 656-660. Reprint of nos. 12, 13, 14: Contributions to Physiology and Pathology, from the Philosophical Transactions-Part II, for 1858. [London: Taylor \& Francis, 1859], pages 607-702. 
15 On the flow of the Lacteal Fluid in the Mesentery of the Mouse. Report of the British Assuciation, 27th meeting, Dublin, 26th August to 2nd September, 1857, part 2, page 114. Also in Quarterly Journal of microscopical Science, 1858, 6, 681-2.

16 On a case of spontaneous Gangrene from Arteritis, and on the Causes of Coagulation of the Blood in Diseases of the Blood Vessels. (Read before the Medico-Chirurgical Society of Edinburgh, 17th March, 1858.) Edinburgh medical Journal, April 1858, 3, 893-907. Reprint. Manuscript: Notes of researches on Coagulation of Blood, 2nd March, 1858 to 1st May, 1860, in hands of Lister and Mrs Lister: R.C.S.

17 Further Experiments on the Coagulation of the Blood. (Medico-Chirurgical Society of Edinburgh, 7th April, 1858.) Edinburgh medical Journal, May 1858, 3, 1049-50.

18 A Case of Ligature of the Brachial Artery, illustrating the persistent Vitality of the Tissues. Edinburgh medical Journal, August 1858, 4, 119-120.

19 Example of mixed Aortic Aneurysm. Edinburgh medical Journal, December 1858, 4, 546.

20 Preliminary Account of an Inquiry into the Functions of the Visceral Nerves, with special reference to the so-called "Inhibitory System." (Received August 13th, 1858.) Proceedings of the Royal Society of London, 1857-59, 9, no. 32, 367-380. Manuscript: notes and " rough draft": R.C.S.

21 Case of Amputation of Leg (Railway accident)-Exhibition of Needle to facilitate Application of Silver wire Sutures. Medico-Chirurgical Society, Edinburgh, March 2nd, 1859. Edinburgh medical Journal, April 1859, 4, 952-4.

22 Some observations on the Structure of Nerve-Fibres, written in collaboration with William Turner. Quarterly Journal of microscopical Science, Oct. 1859, 8, 29-34.

23 Notice of further Researches on the Coagulation of the Blood. Edinburgh medical Journal, December 1859, 5, 536-540. Manuscript: see no. 16.

24 Amputation, in Timothy Holmes A System of Surgery. London: Parker, Son \& Bourn, 1862, 3, 51-90. Manuscript in various hands, with Lister's signature: R.C.S. For revisions see nos. 43 and 83.

25 Anaesthetics [part 1, Chloroform] in the same, pages 91-107. For revisions see nos. 42 and 82. Manuscript, partly autograph, with a later fair copy: R.C.S.

26 On the Coagulation of the Blood. The Croonian Lecture delivered before the Royal Society of London, June 11 th, 1863. Proceedings of the Royal Society, 1863, 12, 580-611. Reprint. Manuscript, with additional notes in Mrs Lister's hand and autograph corrections by Lister: R.C.S.

27 On Excision of the Wrist for Caries. The Lancet, 1865, 1, 308-12 (25 March); 335-8 (1 April); 362-4 (8 April). Drawings, 2 in pencil and 1 in watercolour, by Lister with signed inscriptions, 10, 16 and 21 March 1864: R.C.S. See also no. 47.

28 Notice of a new method of treating compound fractures. Biennial Retrospect of Medicine, etc. (New Sydenham Society) for 1865-6 (1867), p. 219.

29 On a New Method of treating Compound Fracture, Abscess, etc., with Observations on the Conditions of Suppuration. The Lancet, 16 March 1867, 1, 326-9: part 1, on Compound Fracture; 23 March, pages 357-9, continued; 30 March, pages 387-9, continued; 27 April, pages 507-9, continued; 27 July, vol. 2, pages 95-6, Preliminary notice on Abscess. Manuscript in Mrs Lister's hand with notes by Lister: R.C.S.

30 On the Antiseptic Principle in the Practice of Surgery. A paper read before the British Medical Association, Dublin, August 9, 1867. British medical Journal. 21 Sept 1867, 2, 246-8; The Lancet, 21 Sept. 1867, 2, 353-6.

31 Illustrations of the Antiseptic System of Treatment in Surgery. No. 1. The Lancet, 30 Nov. 1867, 2, 668-9.

32 An address on the Antiseptic System of Treatment in Surgery. (Medico-Chirurgical Society of Glasgow, 2 May 1868.) British medical Journal, 1868, 2, 53-6 (18 July): 101-2 (1 August); 461-3 (31 October); 515-7 (14 November). Manuscript with related notes, mainly autograph: R.C.S.

33 Observations on Ligature of Arteries on the Antiseptic System. The Lancet, 3 April 1869. 1, 451-455. Reprint (1): 1869. 14 pages. Reprint (2): 1870. Corrected, 16 pages. Manuscript in Mrs Lister's hand, with corrections, drafts and drawings by Lister: R.C.S.

34 Introductory Lecture [on the Causation of Putrefaction and Fermentation] delivered in the University of Edinburgh, November 8, 1869. British medical Journal, 4 December 1869, 2, 601-604. Reprint: 1869.

35 Obituary notice of the late Joseph Jackson Lister, F.R.S., Z.S., with special reference to his labours in the improvement of the achromatic microscope. Monthly microscopical Journal, 1 March 1870, 3, 134-143. Reprint.

J. J. Lister died on 24 October 1869; the obituary is in the form of a letter dated " Edinburgh, February 8,1870 " to J. B. Reade, President of the Royal Microscopical Society, and was communicated by him at the Anniversary meeting, February 9, 1870. See also no. 96.

36 On the Effects of the Antiseptic System of Treatment upon the Salubrity of a Surgical Hospital, December 1869. The Lancet, 1 and 8 January 1870, 1, 4-6, 40-42. Reprint.

VOL. NO. 49 B, 1, FEBRUARY 1967 
37 The Glasgow Infirmary and the antiseptic Treatment [Letter dated 29 Jan. 1870, answering criticism of his paper (no. 36) by the Managers of Glasgow Infirmary in a letter from their secretary Henry Lamond printed in The Lancet, 29 January 1870, p. 175, and previously in The Glasgow Daily Herald.] The Lancet, 5 Feb. 1870, 1, 210.

38 Remarks on a Case of Compound Dislocation of the Ankle with other Injuries; illustrating the Antiseptic System of Treatment (part of a lecture at the Royal Infirmary of Edinburgh, Feb. 14th 1870). The Lancet, 1870 (19 March), 1, 404-6; (26 March), pages 440-43; (9 April), pages 512-3, dated at end of text "March 26, 1870." Reprint.

39 Further Evidence regarding the Effects of the Antiseptic Treatment upon the Salubrity of a Surgical Hospital. (Dated at end of text “July 22nd, 1870.”) The Lancet, 27 Aug. 1870, 2, 287-289.

40 [Obituary notice of] James Syme. The Scotsman, Edinburgh, 28 June 1870. "Attributed to Lister and never disowned by him " (Godlee Lister, p. 252). Syme, Lister's father-in-law, died on 26 June 1870.

41 A Method of Antiseptic Treatment applicable to Wounded Soldiers in the present War. British medical Journal, 3 Sept. 1870, 2, 243-244.

42 Anaesthetics, in Holmes System of Surgery, 2nd edition, Longmans, Green, 1871, 5, 480-504; revised with new material at pages 496-504. See nos. 25 and 82.

43 Amputation, in the same, pages 592-653. See nos. 24 and 83.

44 On a Case illustrating the present Aspect of the Antiseptic Treatment in Surgery. British medical Journal, 14 January $1871,1,30-32$.

45 Case of Dislocation of the Hip-joint, downwards and inwards, reduced by manipulation. Edinburgh medical Journal, 1871, 16, 243-4.

46 The Address in Surgery [Antiseptic Treatment of Wounds] delivered on August 10, 1871, to the thirty-ninth Annual Meeting of the British Medical Association held in Plymouth. British medical Journal, 26 August $1871,2,225-233$.

47 On some Cases illustrating the Results of the Excision of the Wrist for Caries, the Treatment of Deformity from contracted Cicatrix, and Antiseptic Dressing under some circumstances of difficulty, including Amputation at the Hip-Joint. Medico-Chirurgical Society of Edinburgh, June 6, 1871. Edinburgh medical Journal, August 1871, 17, 144-150. Reprint. The first case is the fifth of those reported in no. 27.

48 On a case of Rupture of the Axillary Artery in an attempt to reduce a dislocation of the shoulder. Medical Times and Gazette, 1 Feb. 1873, 1, 114 (summary); Edinburgh medical Journal, March 1873, 18, 829-831.

49 A further Contribution to the Natural History of Bacteria and the Germ Theory of Fermentative Changes. Quarterly Journal of microscopical Science, October 1873, 13, 380-408, with plates 19-21. Reprint.

50 Case of multiple loose Cartilages in the Elbow-joint, in Sampson Gamgee's "The treatment of wounds on the antiseptic method, being a Report and commentary after a visit to Prof. Lister's Wards in the Royal Infirmary of Edinburgh " [part 2]. The Lancet, 10 January 1874, 1, 50-51.

$51 \mathrm{Mr}$ Lister exhibited [Cases of Omental hernia; tumour of femur; fibrous tumour; a new form of apparatus for producing an antiseptic spray.] Medico-Chirurgical Society, Edinburgh, June 3, 1874. Edinburgh medical Journal, July 1874, 20, 69-73. At page 175 Lister published an apology to Dr James Morton for a claim of priority, at pages 71-72, in his method of treating tumour of the femur.

52 A case of Rodent Ulcer, and a new antiseptic dressing suitable for such cases. Medico-Chirurgical Society, Edinburgh, July 15, 1874. Edinburgh medical Journal, Sept. 1874, 20, 268-270.

$53 \mathrm{Mr}$ Lister exhibited [Cases illustrating " antiseptic management " of articulation of the elbow-joint and pedunculated exostoses]. Medico-Chirurgical Society, Edinburgh, Nov. 11, 1874. Edinburgh medical Journal, Dec. 1874, 20, 556-7.

54 A Contribution to the Germ Theory of Putrefaction and other Fermentative Changes, and the Natural History of Torulae and Bacteria. Read 7 April 1873. Transactions of the Royal Society of Edinburgh, 1875, 27, 313-344, plates 22-26. Reprint. Manuscript: Notes of experiments in the hands of Lister and his wife, and a clerk's fair copy from shorthand notes of the lecture, with corrections by Lister, drawings and proof-plates: R.C.S.

55 On recent improvements in the Details of Antiseptic Surgery. The Lancet, 1875, 1; 13 March, pages 365-7; 20 March, pages 401-2; 27 March, pages 434-6; 3 April, pages 468-70; 1 May, pages 603-5; 22 May, pages 717-9; 5 June, pages 787-9 “ to be concluded," but no more published.

56 Professor Volkmann on Antiseptic Osteotomy. Introductory Note by $\mathrm{Mr}$ Lister. Edinburgh medical Journal, March 1875, 20, 794-9. Reprint.

57 An Address on the Effect of the Antiseptic Treatment upon the General Salubrity of Surgical Hospitals, being the Address delivered in opening the Surgical Section of the British Medical Association at Edinburgh, August 4th, 1875. British medical Journal, 25 December 1875, 2, 769-771. Reprint.

58 Demonstrations of Antiseptic Surgery before Members of the British Medical Association in the Operating Theatre of the Royal Infirmary, Edinburgh, 4th and 5th August 1875. Edinburgh medical Journal, Sept. and Dec. 1875, 21, 193-205; 481-7. Manuscript, fair copy from shorthand notes, with corrections in Lister's hand: R.C.S. 
59 Correspondence with Louis Pasteur: Lister to Pasteur, 10 Feb. 1874, French translation in Pasteur's Etudes sur la Bière, Paris, Gauthier-Villars, 1876, page 43. Pasteur's letters to Lister are printed from the autographs now at R.C.S. in Godlee's Lord Lister, 1917.

60 Address at Edinburgh University Graduation Ceremony, 1st August 1876. Edinburgh medical Journal, Sept. 1876, 22, 280-4.

61 The Antiseptic Method of dressing open Wounds, a clinical lecture delivered at Charity Hospital, New York, Oct. 10, 1876. Medical Record, New York, 21 Oct. 1876, 11, 695-6.

62 Antiseptic Surgery. Transactions of the International Medical Congress, Philadelphia, 1876 (published 1877), pages 535-544. Abstracts in Boston medical and surgical Journal, 14 September 1876, 95, 327-30, and Edinburgh medical Journal, Nov. 1876, 22, 464-7.

63 On the Nature of Fermentation. The Introductory Address delivered in King's College, London, at the opening of the session, 1 October 1877. Quarterly Journal of microscopical Science, April 1878, 18, 177-194. Reprint. Manuscript: fair copy from shorthand notes, with corrections in Lister's hand: R.C.S.

64 [Sur la méthode antiseptique.] Société de Chirurgie de Paris, Séance du 26 juin 1878, communication orale. Bulletin et Mémoires de la Société, 1878, 4, 421-6.

65 Clinical lecture on a Case of Excision of the Knee-joint, and on Horsehair as a Drain for Wounds; with Remarks on the Teaching of Clinical Surgery. Delivered at King's College Hospital, Dec. 10th, 1877. The Lancet, 5 Jan. 1878, 1, 5-9.

66 On the Lactic Fermentation and its Bearings on Pathology. Communication to the Pathological Society, 18 December 1877. Transactions of the Pathological Society of London, 1878, 29, 425-467, and plate 20. Reprint. Manuscript in Mrs Lister's hand, with Lister's notes and drawings: R.C.S.

67 A Case of multiple papillomatous Growths in the Larynx, extirpated by complete Laryngotomy; removal of the whole length of both true and false vocal cords; preservation of the voice; coexistence of thoracic aneurysm, by J. Burney Yeo and Joseph Lister. Read Feb. 22, 1878. Transactions of the Clinical Society, 1878, 11, 104-113; part 2, by Lister, begins at page 107.

$68 \mathrm{Mr}$ Syme's Treatment of incised Wounds. Letter dated Dec. 21st, 1878. The Lancet, 4 January 1879, 1, 28-9.

69 An Address on the Influence of Position upon local Circulation. Read before the Harveian Society of London. British medical Journal, 21 June 1879, 1, 923-6.

70 A Demonstration in Antiseptic Surgery [at the Richmond Hospital, Dublin, 26 June 1879]. Dublin Journal of medical Science, August 1879, 68, 97-114. Reprint.

71 Cases in Mr Lister's Wards, 20th and 27th January 1879. Medical Times and Gazette, 15 Feb. 1879, 1, 175.

$72 \mathrm{Mr}$ Lister's Clinique. [Cases, and Remarks on dressings.] Medical Times and Gazette, 1 Nov. 1879, 2, 502-3.

73 Discours improvisé sur la chirurgie antiseptique. Translation of Address at second general meeting of 6th International Medical Congress, Amsterdam, 9 Sept. 1879, Comptes rendus du Congrès, 1880, page 73. Previously published in German: Ueber antiseptische Wundbehandlung. Allgemeine Wiener medicinische Zeitung, 16 September 1879, 24, 395.

74 Clinical Lecture illustrating Antiseptic Surgery, delivered at King's College Hospital on Nov. 24th, 1879. The Lancet, 20 December 1879, 2, 901-5.

75 Discussion on the Treatment of Wounds. Surgery section, British Medical Association, Cambridge, August 1880. British medical Journal, 28 Aug. 1880, 2, 340-2 and 344.

76 On the Relation of Micro-organisms to Disease. An Address delivered before the Pathological section of the British Medical Association at Cambridge, 12th August 1880. British medical Journal, 4 Sept. 1880, 2 , 363-5; Quarterly Journal of microscopical Science, April 1881, 21, 330-342, with additions. Reprint.

77 President's Address [on the Catgut ligature]. Clinical Society, 28th January 1881. Transactions of the Clinical Society, 1881, 14, xliii-lxiii. Reprint. Previoulsy published in British medical Journal, 5 Feb. 1881, 1, 183-5, with a letter from Lister of 8 Feb., printed 12 Feb. at pages 219-221, and similarly in The Lancet, pages $201-6$ and 275 .

78 An Address on the Relation of minute Organisms to Inflammation, delivered in the Pathological section of the International Medical Congress, 5 August 1881. Transactions of the 7th Congress, London, 1881, 1, 311-319. Reprint.

79 An Address on the Treatment of Wounds, delivered in the Surgical section of the International Medical Congress, 8 August 1881, in concluding the discussion on the subject. Transactions [as no. 78], 2, 369-383. Reprint. Also published in The Lancet, 19 and 26 Nov. 1881, 2, 863-6 and 901-3.

80 On the applicaton of a knowledge of hydrostatics and hydraulics to practical medicine. Address to the Medical Society of University College, 11 Oct. 1882. [Reported in third person.] The Lancet, 14 Oct. 1882, 2, 638-9.

81 Mr Lister's Clinic: Gunshot wound of the left forearm [etc.]. Medical Times and Gazette, 2 Dec. 1882, 2, 660-1.

82 Anaesthetics in Holmes System of Surgery, 3rd edition, 1883, 3; part 1 " written 1861," pages 598-607; part 2 " written 1870," pages 607-611; part 3 [ether] "written 1882," pages 611-624. See nos. 25 and 42.

VOL. 49 B, NO. 1, FEBRUARY 1967 
83 Amputation, part 1, in Holmes [as no. 82], pages 697-722. Part 2 on Artificial limbs is by W. Watson Cheyne. See nos. 24 and 43.

84 An Address on the Treatment of Fracture of the Patella, delivered at the Medical Society of London. 29 Oct. 1883. Transactions of the Medical Society (1884), 7, 8-28; British medical Journal, 3 Nov. 1883, 2, 855-60; The Lancet, [same day], 761-5.

85 An Address on Corrosive Sublimate as a Surgical Dressing, delivered at the Medical Society of London, 20 Oct. 1884. Transactions of the Medical Society, (1885), 8, 2-19; British medical Journal, 25 Oct. 1884, 2, 803-7; The Lancet, [same day], 723-8.

86 The present position of Antiseptic Treatment. Bradshaw Lecture, Royal College of Surgeons of England, 7 December 1887.

According to Godlee it was " not reported even in abstract, and there was no record of it among Lister's papers."

87 An Address on a New Antiseptic Dressing, [the " so-called double salt," cyanide of zinc and mercury] delivered before the Medical Society of London, 4 Nov, 1889. Transactions of the Medical Society (1890), 13, 32-50; British medical Journal, 9 Nov. 1889, 2, 1025-9; The Lancet, [same day], 943-7; Illustrated medical News, London, [same day], 5, 125-7.

88 Two cases of long-standing Dislocation of both Shoulders treated by Operation, with further observations on the Cyanide of Zinc and Mercury. Read before the Hunterian Society on November 27th, 1889. Abstract of the Transactions of the Hunterian Society, 1889-90, pages 91-104; British medical Journal, 4 Jan. 1890, 1, 1-4; The Lancet, [same day], 1-4.

89 An Address on the present position of Antiseptic Surgery delivered before the International Medical Congress at Berlin, August 1890. Verhandlungen des X. Congresses, Berlin (1891), 1, 28-35. Reprint. British medical Journal, 16 August 1890, 2, 377-9.

90 Lecture on Koch's Treatment of Tuberculosis, delivered at King's College Hospital, December 3rd, 1890. British medical Journal, 13 Dec. 1890, 2, 1372-4; The Lancet, [same day], 1257-9.

91 On the Principles of Antiseptic Surgery. Internationale Beiträge zur wissenschaftliche Medicin, Festschrift Rudolf Virchow gewidmet zur Vollendung seines 70. Lebensjahres. Berlin: August Hirschwald, 1891, 3, 259-270, with facsimile inscription at the end: Joseph Lister/London/April 1891. Reprint.

92 On the Coagulation of the Blood in its practical Aspects. The Annual Oration to the Medical Society of London delivered May 4th, 1891. Transactions of the Medical Society, 1891, 14, 413-25. Reprint. Summary in Medical Press and Circular, 6 May 1891, 102, 449-50; full text in British medical Journal, 16 May 1891, 1, 1057-60, and The Lancet, [same day], 1081-4.

93 Introductory Address in Section of Bacteriology of the International Congress of Hygiene, London, August 1891. Transactions of the 7th Congress, (1892), 2, section 2, pages 9-10; The Lancet, 15 August 1891, 2, $375-6$.

94 [Speech in honour of Louis Pasteur] Paris, 27 December 1892. French text in: 1822-1892 Jubilé de M. Pasteur. Paris: Gauthier-Villars, 1893, pages 16-17.

95 An Address on the Antiseptic Management of Wounds, delivered at King's College Hospital in the London Post-Graduate Course, Jan. 18th, 1893. British medical Journal, 28 Jan. 1893, 1, 161-2; 11 Feb., pp. 277-8; 18 Feb., pp. 337-9; The Lancet, [same days], pp. 179-80, 285-6, 297-8. Additional “ Note by Lord Lister, 1907," in Collected Papers, 2, 355.

96 Lister, Joseph Jackson. Dictionary of National Biography, 1893, 33, 347-50; signed J. L. See also no. 35.

97 On the Simplification of the Antiseptic Treatment. Address to the Glasgow University Medico-Chirurgical Society, 17 May 1894. Glasgow medical Journal, June 1894, 41, 434-9. Manuscript, partly autograph: R.C.S.

98 Address by the President [on the Interdependence of Science and the Healing Art], Liverpool, 16 Sept. 1896. Report of the British Association, 1896, 66, 3-27; British medical Journal, 19 Sept. 1896, 2, 733-41, “ On the relations of clinical medicine to modern scientific development." Reprint.

99 The Royal Society. The Address of the President delivered at the Anniversary Meeting, 30 Nov. 1896. Year Book of the Royal Society, 1896-7, pages 119-137. Reprint.

100 Jenner Memorial. Report of preliminary meeting, held on December 7th, 1896 [in the Board Room of St George's Hospital. Sir Joseph Lister, P.R.S., in the Chair]. London: Adlard \& Son, January 31st, 1897.

101 An Address of the Value of Pathological Research delivered on January 20th, 1897, in connection with the opening of the New Physiological and Pathological Laboratories in Queen's College, Belfast, during the celebration of the Jubilee of the College. British medical Journal, 6 Feb. 1897, 1, 317-9.

102 Jenner Memorial. Report of Public Meeting held on March 31st, 1897 [in the Theatre of the University of London]. Adlard \& Son.

103 House of Lords, Session 1897. British Troops in India (Health). Speech by Lord Lister on Monday 17th May 1897. Reprinted from the Parliamentary Debates, Authorised edition.

104 Royal Society. Address of the President, 1897. Year Book of the Royal Society, 1897-8, 2, 132-148. Reprint. 
105 House of Lords. Speech on the Vaccination Bill, Thursday, August 4th, 1898. British medical Journal, 13 Aug. 1898, 2, 429-30.

106 Lord Lister's Address. Opening of the Thompson-Yates Laboratories of Liverpool University College, October 8th, 1898. British medical Journal, 15 Oct. 1898, 2, 1190-1.

107 Royal Society. Address of the President, 1898. Year Book of the Royal Society, 1899, 3, 142-160. Reprint.

108 Royal Society. Address of the President, 1899. Year Book of the Royal Society, 1900, 4, 143-157. Reprint.

109 Introduction to Experiments on Animals, by Stephen Paget, London, 1900; 2nd edition 1903; 3rd edition 1906.

110 On early Researches leading up to the Antiseptic System of Surgery. Third Huxley lecture delivered before the Medical School of Charing Cross Hospital, 2nd October 1900. British medical Journal, 6 Oct. 1900, 2, 969-77; The Lancet, [same day], 985-93. Separate issue, 1907.

111 On recent Researches with regard to the Parasitology of Malaria. British medical Journal, 8 Dec. 1890, 2, 1625-7.

112 Royal Society. Address of the President, 1900. Year Book of the Royal Society, 1901, 5, 150-69. Reprint.

113 Note [on the double cyanide of mercury and zinc as an antiseptic dressing]. British medical Journal, 6 April 1907, 1, 795-6, in Sir Hector Cameron's " Lord Lister and the evolution of Wound treatment during the last forty years." (Dr James Watson Lectures, Faculty of Physicians and Surgeons, Glasgow, July 1906.)

114 Note on the Preparation of Catgut for Surgical Purposes. British medical Journal, 18 Jan. 1908, 1, 125-6; The Lancet, [same day], 1, 148-9.

115 Remarks on the Treatment of Fractures of the Patella of long standing. [A private letter of September 15th, 1895.] British medical Journal, 11 April 1908, 1, 849-50; The Lancet, [same day], 1049-50.

116 Remarks on some Points in the History of Antiseptic Surgery, " unfinished Letter to Sir Hector Cameron written early in 1906 before his Lectures [no. 113], but never sent to him," British medical Journal, 27 June 1908, 1, 1557-8; The Lancet, [same day], 1815-6.

117 On sulpho-chromic Catgut [Letter dated Jan. 14th, 1909]. British medical Journal, 23 Jan. 1909, 1, 245; The Lancet, [same day], 273. 